\title{
Shear Behavior of Steel Fiber Reinforced Concrete Wide Beams without Stirrups
}

\section{Alaa M Morsy ${ }^{1 *}$ and El-Raki TM²}

${ }^{1}$ College of Engineering and Technology, Arab Academy for Science, Technology and Maritime Transport, Egypt

${ }^{2}$ Housing and Building National Research Center, Cairo, Egypt

\begin{abstract}
Twelve simply-supported steel fiber reinforced concrete (SFRC) wide beams without conventional stirrups were tested to investigate their shear behavior. The flexure mode of failure was secured for all of the specimens to allow for shear mode of failure. The variables were fiber volumetric ratio, concrete compressive strength, longitudinal reinforcement ratio and shear span-to-depth ratio. Eight tested beams were steel fiber reinforced concrete wide beams and four beams were reinforced concrete wide beams without steel fiber for comparison purposes. End-hooked steel fibers of volumetric ratio ranging from $0 \%$ to $1.25 \%$ were used in the specimens. All beams were tested under four-point loading to investigate their behavior in shear, cracking pattern, ultimate capacity and ductility. Test results showed that the shear cracking, the ultimate shear strength and ductility increased with increasing fiber volumetric ratio, decreasing shear span to depth ratio, increasing concrete compressive strength and increasing longitudinal reinforcement ratio. The using of a dose of $0.75 \%$ fiber content in the wide beams without shear stirrups was adequate to achieve the ultimate resistance that is the same as the conventional RC wide beam with conventional stirrups. Evaluation of the ultimate shear strength of the SFRC wide beams based on previous models is presented.
\end{abstract}

Keywords: Steel fiber reinforced concrete; Stirrups; Shear strength; Wide beams

\section{Introduction}

In the design of buildings, modern architectural constraints are pushing engineers to provide longer clear spans at a reasonable cost. At the same time, there is a need to minimize the overall structural depth, which can be achieved through the use of wide beams. On the other hand, the use of natural fibers to reinforce building materials had been known since the era of the ancient Egyptians. The fibers that are currently being used include steel, glass and polypropylene. The addition of discontinuous and randomly oriented steel fibers to concrete offers a convenient and practical means of improving many of the engineering properties of the material such as, flexural strength, compression strength, shear strength and ductility. The effectiveness of fiber reinforcement to increase shear resistance, however, is dependent on several factors, including fiber properties (that is, material properties, aspect ratio, and shape), fiber content, and bond stress versus slip response of fibers, $[1,2]$. The literature describes several studies of fiber-reinforced regular beams with and without stirrups. Batson et al. [3] performed the first large experimental study of such beams which included 42 tests of fiber-reinforced beams without stirrups that failed in shear. Subsequent investigations of normal-strength concrete $[4,5]$ and high-strength concrete [6,7], confirmed the effectiveness of adding steel fibers and identified key parameters that affect shear strength. In these studies, the effect of several parameters, such as shear span to depth ratio (a/d), longitudinal reinforcement ratio $\rho$, fiber volumetric ratio $V_{\rho}$ and concrete compressive strength $f_{\text {cu }}$ on the shear strength of SFRC slender beams have been considered. Test results showed that the increase in shear strength can vary drastically depending on the beam geometry and material properties. For example, in tests reported by Narayanan and Darwish [8] the increase in shear strength attributable to steel fibers varied from 13 to $170 \%$. Dinh et al. [2] conducted a series of large-scale tests on a total of 24 simply supported SFRC test specimens under monotonically increased load and concluded that the fiber content had a strong influence on the shear strength of SFRC members as compared with the percentage of longitudinal reinforcement and the effective depth. However, the contribution of steel fibers in enhancing the shear strength of reinforced concrete members has been recognized in ACI 318-08 [9]. The code recommends the use of deformed steel fibers as a partial replacement to the shear stirrups in the flexural members for the fiber amount greater than or equal to $0.75 \%$ of the volume. This recommendation is only applicable if the value of factored shear force $V u$ does not exceed $1 / 6 \varphi b d V f c^{\prime}\left(f c^{\prime}\right.$ in $\mathrm{MPa}$ ) where $\varphi$ is the strength reduction factor (0.75), $b$ is the web width, $d$ is the member effective depth, and $f c^{\prime}$ is the concrete cylinder strength. The incorporation of steel fibers also significantly enhances the load-carrying capacity and the ductility of the deep concrete beams with and without openings [10].

Nevertheless, investigators have also developed empirical expressions for calculating shear strength of SFRC slender beams. For example, Ashour et al. [6], Narayanan and Darwish [8], Sharma [11], and Imam et al. [12] have proposed equations for predicting the ultimate shear stress $\mathrm{V} u$. Further study, however, is required to investigate the overall behavior of the SFRC wide beams for the various combinations of shear span-depth ratio, fiber content, grade of concrete, percentage of longitudinal reinforcement, and transverse stirrups. The objectives of this study are to evaluate the effect of these parameters on the shear behavior, failure mode, crack propagation, and ductility of the SFRC beams without shear stirrups. Also, the observed shear strength values were compared with those predicted by the existing models.

\section{Experimental Program}

\section{Details of test specimens}

The experimental program consisted of twelve half-scale beam specimens with a span of $1200 \mathrm{~mm}$, and a rectangular cross section of $450 \mathrm{~mm}$ wide and $200 \mathrm{~mm}$ thickness. The tested beams were divided into four series B1 to B4 and each series consisted of three specimens. The steel fiber ratio in each specimen in all series was 0, 0.75 and $1.25 \%$. All specimens were supported on roller assemblies and knife edges to allow longitudinal motion and rotation. Each specimen was loaded with

*Corresponding author: Alaa M. Morsy, College of Engineering and Technology, Arab Academy for Science, Technology and Maritime Transport, Egypt, Tel: 002-034865087; E-mail: alaamorsy@gmail.com

Received September 26, 2017; Accepted January 12, 2018; Published January 18,2018

Citation: Morsy AM, El-Raki TM (2018) Shear Behavior of Steel Fiber Reinforced Concrete Wide Beams without Stirrups. J Civil Environ Eng 8: 292. doi: 10.4172/2165-784X.1000292

Copyright: @ 2018 Morsy AM, et al. This is an open-access article distributed under the terms of the Creative Commons Attribution License, which permits unrestricted use, distribution, and reproduction in any medium, provided the original author and source are credited. 
Citation: Morsy AM, El-Raki TM (2018) Shear Behavior of Steel Fiber Reinforced Concrete Wide Beams without Stirrups. J Civil Environ Eng 8: 292. doi: $10.4172 / 2165-784 X .1000292$

Page 2 of 9

\begin{tabular}{|c|c|c|c|c|c|c|c|c|c|c|c|}
\hline \multirow[b]{2}{*}{ 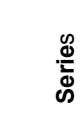 } & \multirow{2}{*}{ 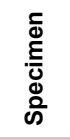 } & \multirow[b]{2}{*}{$a / d$} & \multirow[b]{2}{*}{ Fiber vol. ratio $\mathrm{V}_{f}(\%)$} & $\mathbf{f}_{\mathrm{cu}}$ & $\rho \log$ & $\varepsilon_{\text {smax }}$ & $\mathbf{P}_{\mathrm{u}}{ }^{*}$ & \multirow[b]{2}{*}{$\mathbf{P}_{\mathrm{cr}}^{* *}$} & \multirow{2}{*}{$\begin{array}{l}{ }^{\wedge} \Delta_{\mathrm{m}} \\
\mathrm{mm}\end{array}$} & \multirow{2}{*}{$\begin{array}{c}\mathbf{V}_{\mathrm{u}}^{* * *} \\
/\left(\mathbf{b d}{\sqrt{\mathbf{f}_{\mathrm{cu}}}}\right)\end{array}$} & \multirow[b]{2}{*}{ Z\# } \\
\hline & & & & (MPa) & $\%$ & $\times 10^{-3}$ & $(\mathrm{kN})$ & & & & \\
\hline \multirow{3}{*}{$\bar{\oplus}$} & B1-1 & 1.8 & 0 & 27 & 3 & 1.1 & 446 & 250 & 4.7 & 0.55 & 1 \\
\hline & B1-2 & 1.8 & 0.75 & 28 & 3 & 1.3 & 551 & 300 & 5.8 & 0.67 & 1.22 \\
\hline & B1-3 & 1.8 & 1.25 & 27.8 & 3 & 1.6 & 647 & 315 & 7.6 & 0.79 & 1.44 \\
\hline \multirow{3}{*}{ ๗ิ } & B2-1 & 1.8 & 0 & 50 & 3 & 1.6 & 750 & 340 & 6.4 & 0.68 & 1 \\
\hline & B2-2 & 1.8 & 0.75 & 49 & 3 & 1.8 & 836 & 400 & 8 & 0.76 & 1.12 \\
\hline & B2-3 & 1.8 & 1.25 & 50.8 & 3 & 1.95 & 980 & 470 & 9.4 & 0.87 & 1.28 \\
\hline \multirow{3}{*}{$\mathscr{m}$} & B3-1 & 1.8 & 0 & 29 & 2 & 1.2 & 363 & 220 & 5.5 & 0.43 & 1 \\
\hline & B3-2 & 1.8 & 0.75 & 31 & 2 & 1.4 & 430 & 250 & 6.7 & 0.49 & 1.14 \\
\hline & B3-3 & 1.8 & 1.25 & 31.5 & 2 & 1.8 & 541 & 280 & 8.9 & 0.61 & 1.42 \\
\hline \multirow{3}{*}{ Đ } & B4-1 & 2.4 & 0 & 27 & 3 & 0.7 & 257 & 215 & 6.1 & 0.32 & 1 \\
\hline & B4-2 & 2.4 & 0.75 & 27 & 3 & 1.6 & 435 & 275 & 8.8 & 0.52 & 1.69 \\
\hline & B4-3 & 2.4 & 1.25 & 28 & 3 & 1.7 & 508 & 305 & 9.7 & 0.61 & 1.94 \\
\hline \multicolumn{12}{|c|}{$\begin{array}{c}{ }^{*} \text { The maximum applied loa } \\
{ }^{* *} \text { The approximate value of } \\
{ }^{* * *} \text { The maximum shear stre } \\
{ }_{\mathrm{m}}=\text { Deflection at } 80 \% \text { of } \\
\# Z=\frac{V u / \sqrt{f c u} b d}{V u / \sqrt{f c u} b d}(\text { R.C.) }\end{array}$} \\
\hline
\end{tabular}

Table 1: Beams grouping and test results.
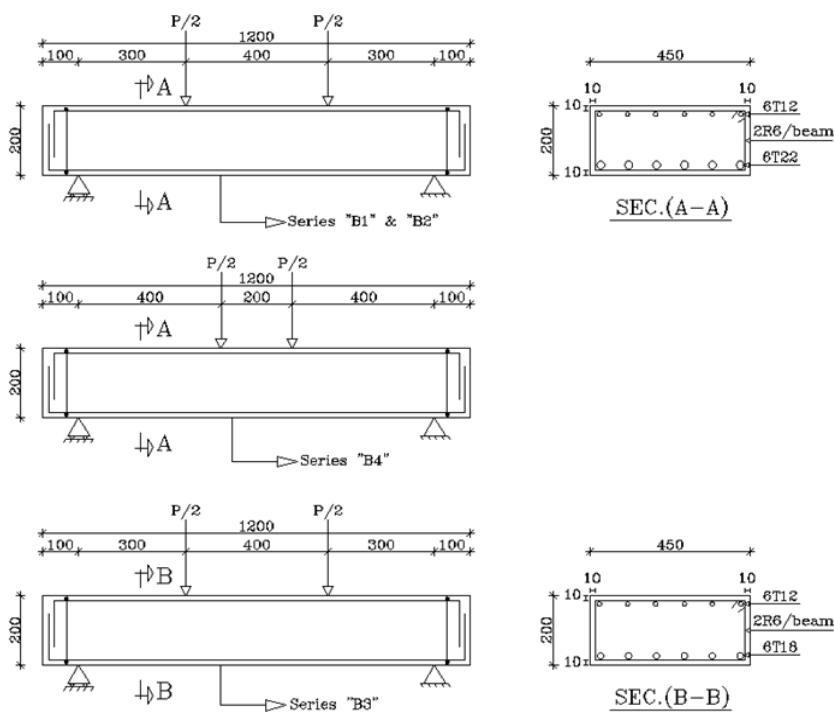

Figure 1: Details of tested beams.

four points loading with shear span to effective depth ratio equal to 1.8 for Series B1, B2 and B3, and 2.4 for Series B4. The load was applied as a static load. To induce a shear failure, the beams were reinforced longitudinally with six $22-\mathrm{mm}$ bottom steel bars resulting longitudinal reinforcement ratio $3 \%$ for groups B1, B2 and B4 and six 18-mm bottom steel bars with reinforcement ratio $2 \%$ for group B3. Six $12-\mathrm{mm}$ top steel bars for all beams as compression reinforcement with ratio $0.9 \%$ were provided. Beams were reinforced transversely with 8 -mm diameter steel stirrups hangers at the start and end of beams. The target concrete compressive strength was $25 \mathrm{MPa}$ for groups B1, B3 and B4 and it was $50 \mathrm{MPa}$ for group B2, Table 1 . Concrete cover was $15 \mathrm{~mm}$, typical concrete dimensions and reinforcement details of the test specimens are illustrated in Figure 1. In addition, the shear behavior of beam SB5, tested by Said M. and El-Rakib [13], will be discussed for comparison purpose. Beam SB5 had the same aspects of B4-1 but it was vertically reinforced by conventional steel stirrups $\mathrm{R} 8 / 150 \mathrm{~mm}$ with four legs.

\section{Materials used}

Ordinary Portland cement, fine aggregates and coarse aggregates of maximum size of $20 \mathrm{~mm}$ were used in the concrete mixtures. Two types of concrete mix were required. A normal strength concrete with specified nominal strength of $25 \mathrm{MPa}$ at 28 days represents Mix 1. Mix 2 represents higher strength concrete with specified nominal strength of $50 \mathrm{MPa}$ at 28 days. Silica fume was added to mix of target cubic strength of $50 \mathrm{MPa}$. The super-plasticizer dose was adjusted to achieve a reasonable level of workability, for a slump of about $70 \mathrm{~mm}$, and was used in Mix 2. Three concrete cubes, for each beam, were tested in compression on the day of the test of the corresponding specimens. 
Citation: Morsy AM, El-Raki TM (2018) Shear Behavior of Steel Fiber Reinforced Concrete Wide Beams without Stirrups. J Civil Environ Eng 8: 292. doi: $10.4172 / 2165-784 X .1000292$

Page 3 of 9

The results of the actual compressive strength tests are listed earlier in Table 1. Table 2 gives the quantities of materials required for one cubic meter of fresh concrete for the two concrete mixes. It was noted that no significant difference was noted in the concrete compressive strength by adding the steel fibers into the concrete mixture. Deformed high tensile steel of $(12,18$ and 22) $\mathrm{mm}$ diameter with nominal yield strength of $400 \mathrm{MPa}$ and ultimate strength of $600 \mathrm{MPa}$ was used as main tension reinforcement and top reinforcement for all tested beams.

\section{Test setup and instrumentation}

Test specimens were instrumented to measure the applied load, mid-span deflection, and strains of longitudinal reinforcement at the critical sections. A linear variable displacement transducer (LVDT) for measuring deflection was mounted at the bottom side of the midspan for each specimen. Two electrical resistance strain gauges mounted on the longitudinal reinforcement were used to measure the steel strains up to yielding. Load was applied using a hydraulic jack of $2000 \mathrm{kN}$ capacity

\begin{tabular}{|c|c|c|}
\hline \multirow{2}{*}{ Constituents } & \multicolumn{2}{|c|}{ The quantity required for $\left.\mathbf{1}^{\mathbf{3}} \mathbf{( k g}\right)$} \\
\cline { 2 - 3 } & $\boldsymbol{M i x} \mathbf{( 1 )} \boldsymbol{f}_{\mathrm{cu}}=\mathbf{2 5} \mathbf{M P a}$ & $\boldsymbol{M i x} \mathbf{( 2 )} \boldsymbol{f}_{\mathrm{cu}}=\mathbf{5 0} \mathbf{M P a}$ \\
\hline Cement & 350 & 450 \\
\hline Silica fume & -- & 15 \\
\hline Coarse aggregate & 1120 & 1180 \\
\hline Sand & 685 & 620 \\
\hline Total water & 175 & 136 \\
\hline Super-plasticizer & -- & 10 \\
\hline
\end{tabular}

Table 2: Concrete mix proportions per one cubic meter.
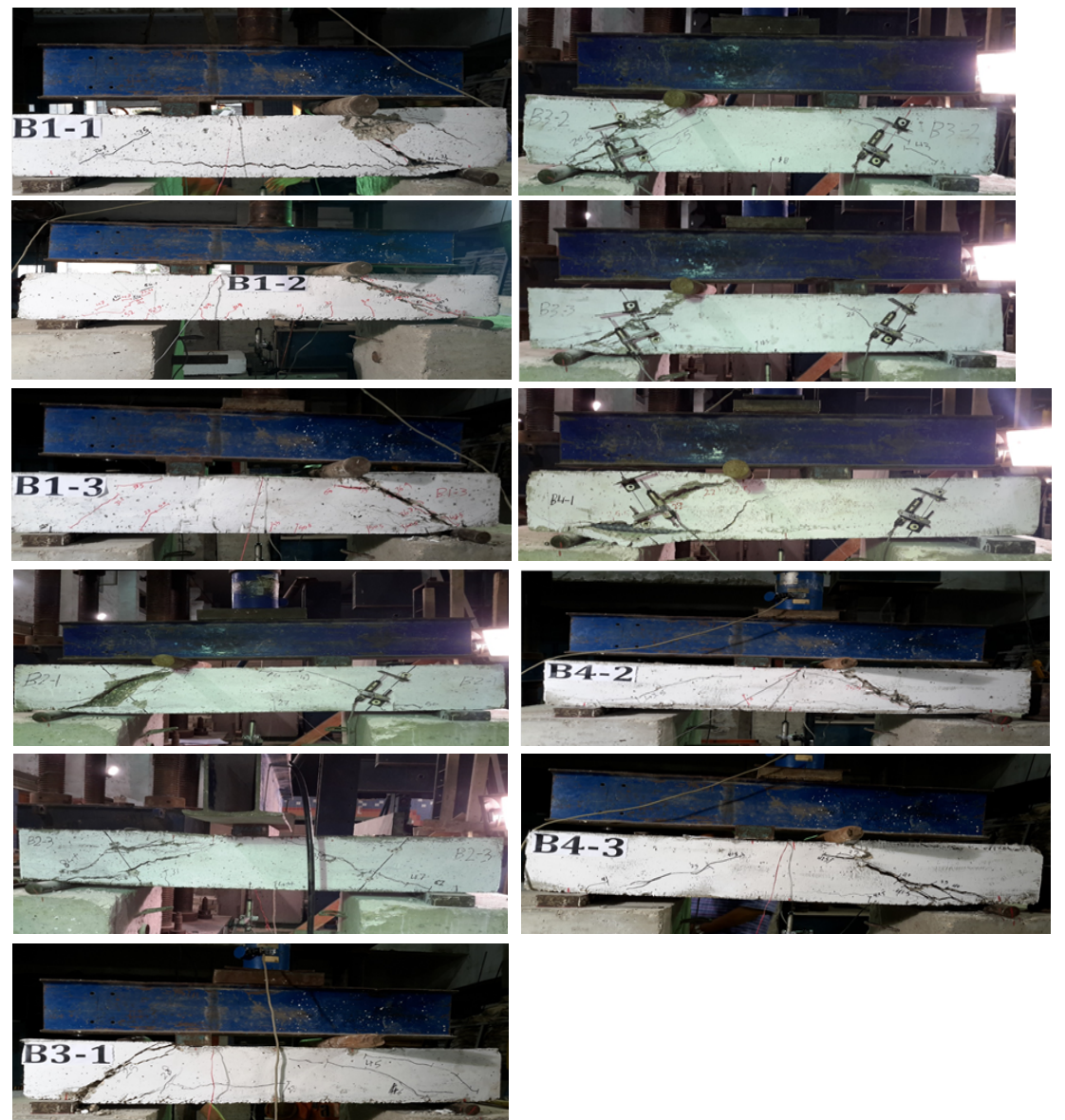

in compression. The jack was equipped with a calibrated load cell of \pm $1200 \mathrm{kN}$ capacity to measure the applied load. The load was distributed equally by a spreader beam to two points along the specimen. The test was continued after the ultimate load in order to evaluate the post peak behavior of the tested beams. During testing, the general deformational behavior was tracked. The development of cracks was marked along the sides of the specimens. At each load stage, the electrical strain gauges, load cells and (LVDT) voltages were fed into the data acquisition system. The voltage excitations were read, transformed and stored as micro strains, force, and displacement by means of a computer program that runs under the Lab View software. Data obtained from these gauges were later used to estimate the cracking and the ultimate loads of the test specimens.

\section{Test Results}

\section{Cracking behavior and mode of failure}

Typical behavior of SFRC beams is introduced through crack pattern distribution recorded at applied load increments as shown in Figure 2. For all specimens, the first crack development, crack propagation, and plane of failure were remarked during the test. As stated before; all tested specimens were designed to fail in shear and this presumption was investigated for all tested SFRC beams. The crack development approximately followed a similar pattern in all of the tested specimens. The tested beams were free of cracks in the early stages of loading. For specimens B1-1, B2-1, B3-1 and B4-1 the inclined shear cracks started first without appearance of flexural cracks. For other SFRC beams, cracks started to develop at mid span, and

Figure 2: Cracking pattern of specimens. 

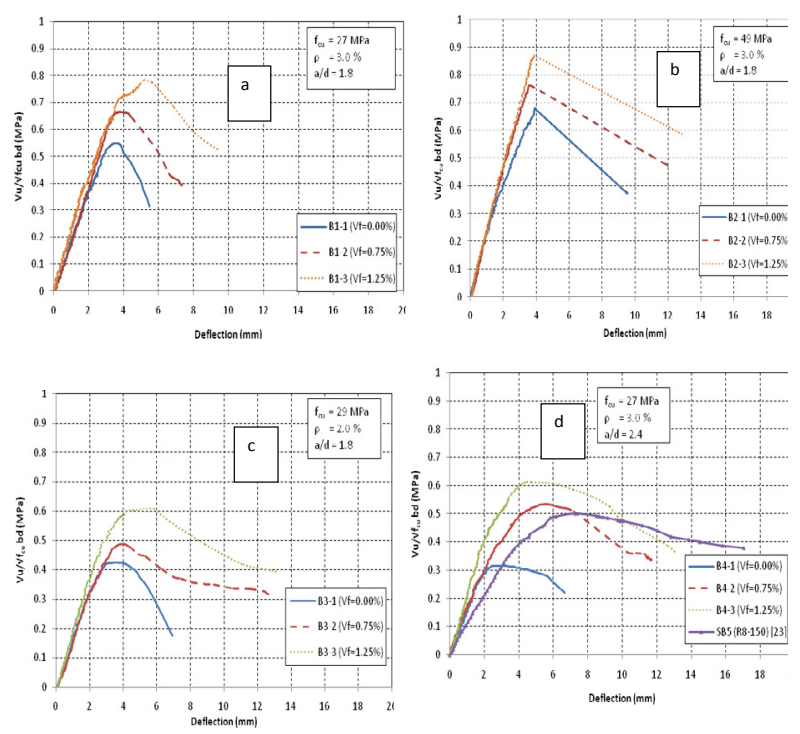

Figure 3: Normalized shear resistance -deflection curves for all series and SB5 [13]

then inclined shear cracks appeared starting from the support point towards the load point. With the increase of the load, the number and the width of these cracks increased especially the inclined shear cracks. At the last stages of loading before failure, the existing diagonal cracks rapidly widened and extended upwards to the loading point up to failure of the beams. During the shear failure and after occurrence of the crushing mechanism in the compressive concrete, cracking along the longitudinal reinforcement towards the support region was also observed in specimens B1-1, B2-1, B3-1, B4-1 and B4-2. Steel fibers had a noticeable effect on cracks initiation and distribution for the tested beams. SFRC Beams with steel fibers showed more delay of cracking initiation and also more uniform and distributed cracks than beams without steel fiber. The mode of failure of all SFRC specimens was shear mode of failure characterized by diagonal shear tension mode of failure as shown in Figure 2.

Table 1 summarizes the results of the tested beam specimens. The table gives the main characteristics of each specimen, the shear cracking load, the ultimate load and the ultimate shear stress.

\section{Normalized shear resistance-deflection relationship}

The shear resistance $V u$ values are normalized with respect to a factor (bd $\mathrm{f}_{\mathrm{cu}} 0.5$ ) and plotted against midspan displacements for all tested beams (Figure 3).

Series B1 includes three specimens B1-1, B1-2 and B1-3 which were considered as reference specimens for the tested program globally. Beam B1-1 was control specimen without steel fiber, while, Beams B1-2 and B1-3 had steel fibers with volumetric ratio $\left(\mathrm{V}_{f}\right) 0.75 \%$ and $1.25 \%$ respectively. Regarding to Figure $3 \mathrm{a}$, the normalized shear resistance -deflection curves of series B1 showed generally three main stages; linear up to the first crack and a nonlinear one which begins with cracking at the mid span followed by reduction in stiffness and end with a large number of cracks and eventually a descending stage at which the beams were subjected to plastic deformations and wide cracks until failure occurs. The ultimate normalized shear resistance value increased by $22 \%$ when using $0.75 \%$ volumetric fibers ratio and by $44 \%$ when using $1.25 \%$ volumetric fibers ratio. Table 1 shows an increase in the shear cracking load by $20 \%$ when using $0.75 \%$ volumetric fibers ratio and by $26 \%$ when using $1.25 \%$ volumetric fibers ratio. The previous ratios provide proof of the more favorable behavior and the contribution of steel fibers in resisting shear.
Series B2 includes three specimens B2-1, B2-2 and B2-3 which had average concrete compressive strength $49 \mathrm{MPa}$. These beams were tested to investigate the effect of concrete compressive strength globally between series B1 and B2 and locally the effect of steel fiber volumetric ratio between these specimens in this group on the shear behavior of SFRC wide beams. Beam B2-1 was the control specimen without steel fibers while specimens B2-2 and B2-3 had steel fibers with volumetric ratio $\left(\mathrm{V}_{f}\right) 0.75 \%$ and $1.25 \%$ respectively. Regarding to Figure $3 \mathrm{~b}$, the normalized shear resistance -deflection curves showed generally two main stages; linear up to the first crack, nonlinear one which begins with cracking at the mid span followed by reduction in stiffness and end with a wide crack until sudden failure occurs. The ultimate normalized shear resistance value increased by $12 \%$ when using $0.75 \%$ volumetric fibers ratio and by $28 \%$ when using $1.25 \%$ volumetric fibers ratio. Table 1 shows an increase in the shear cracking load by $18 \%$ when using $0.75 \%$ volumetric fibers ratio and by $38 \%$ when using $1.25 \%$ volumetric fibers ratio.

Series B3 includes three specimens B3-1, B3-2 and B3-3 which had longitudinal reinforcement ratio $2 \%$. These beams were tested to investigate the effect of longitudinal reinforcement ratio globally between series B1 and B3 and locally the effect of steel fibers volumetric ratio between these specimens in this group on the shear behavior of SFRC wide beams. Beam B3-1 was the control specimen without steel fibers. While, Beams B3-2 and B3-3 had steel fibers with volumetric ratio $\left(\mathrm{V}_{f}\right) 0.75 \%$ and $1.25 \%$ respectively. Regarding to Figure $3 \mathrm{c}$, the normalized shear resistance -deflection curves showed generally three main stages; linear up to the first crack, nonlinear one which begins with cracking at the mid span followed by reduction in stiffness and end with a large number of cracks and eventually a descending stage at which the beams were subjected to plastic deformations and wide cracks until failure occurs. The ultimate normalized shear resistance value increased by $14 \%$ when using $0.75 \%$ volumetric fibers ratio and by $42 \%$ when using $1.25 \%$ volumetric fibers ratio. Table 1 shows an increase in the shear cracking load by $14 \%$ when using $0.75 \%$ volumetric fibers ratio and by $27 \%$ when using $1.25 \%$ volumetric fibers ratio.

Series B4 includes three specimens B4-1, B4-2 and B4-3 which had shear span to depth ratio 2.4 . These beams were tested to investigate 


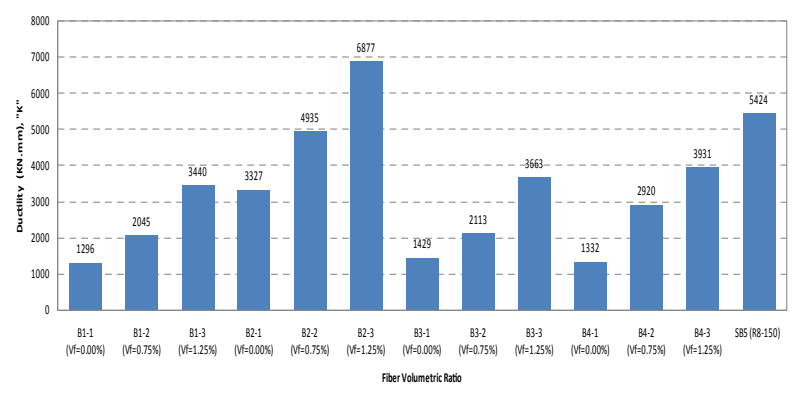

Figure 4: Ductility of the tested specimens and SB5 [13].

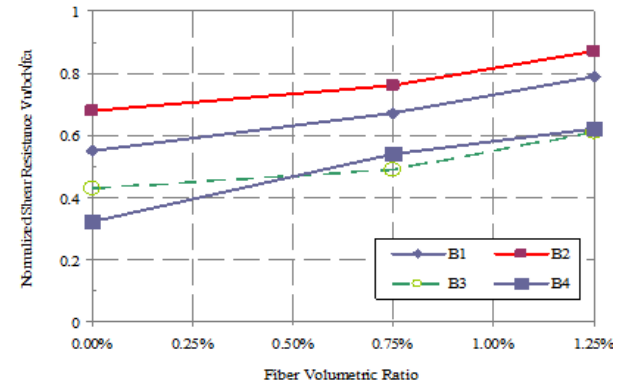

Figure 5a: Effect of fiber volumetric ratio on normalized shear resistance of all series.

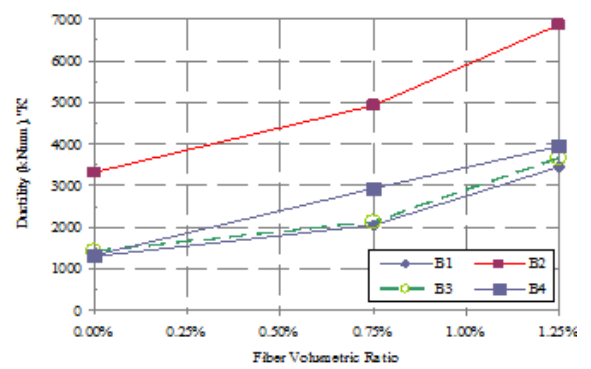

Figure 5b: Effect of fiber volumetric ratio on ductility of all series

the effect of shear span to depth ratio globally between series B1 and B4 and locally the effect of steel fiber volumetric ratio between these specimens in this group on the shear behavior of SFRC wide beams. Beam B4-1 was the control specimen without steel fibers. While, Beams B4-2 and B4-3 had steel fibers with volumetric ratio $\left(V_{f}\right) 0.75 \%$ and $1.25 \%$ respectively. As stated before, the shear behavior of beam SB5, tested by Said M. and El-Rakib [13], will be discussed for comparison purpose. Regarding to Figure $3 \mathrm{~d}$, the normalized shear resistance -deflection curves showed generally three main stages similar to series $\mathrm{B} 1$ and B3. The ultimate normalized shear resistance value increased by $69 \%$ when using $0.75 \%$ volumetric fibers ratio and by $94 \%$ when using $1.25 \%$ volumetric fibers ratio. Table 1 shows an increase in the shear cracking load by $28 \%$ when using $0.75 \%$ volumetric fibers ratio and by $42 \%$ when using $1.25 \%$ volumetric fibers ratio. The previous ratios provide proof of the more favorable behavior and the contribution of steel fibers in resisting shear.

On the other hand, test results showed that the ultimate normalized shear resistance value of SB5 [13], B4-2 and B4-3 was 0.50, 0.54, and 0.61 respectively. Although the shear steel stirrups were completely eliminated in the SFRC specimens, the normalized shear resistance values were nearly equal to or higher than that of the corresponding RC specimen SB5 with conventional steel stirrups. It may be reported that the addition of $0.75 \%$ steel fiber content in the SFRC beams without shear stirrups is sufficient to achieve the ultimate shear resistance that is the same as the conventional RC member with steel stirrups.

\section{Ductility of specimens}

Ductility is the ability of the reinforced concrete member to sustain large inelastic deformations without excessive strength deterioration. The ductility can either be represented in terms of the ratio of maximum displacement to the yield displacement, both measured at mid span, or in terms of the displacement energy consumed by the specimen during the test measured as the area under the load displacement curve till the failure load which can be considered $80 \%$ of the of the ultimate load on the descending branch of the load-deflection curve [14]. Since the flexure mode of failure was prevented for all specimens to allow for shear mode of failure, it was found more suitable to use the second measure of ductility. Figure 4 shows displacement energy measured for all tested specimens, $\mathrm{k}$. The figure undoubtedly shows that the increase in steel fiber volumetric ratio generally increases the ductility.

\section{Strains in longitudinal steel reinforcement}

Two electrical strain gages were attached to longitudinal steel reinforcement per specimen. Table 1 shows the maximum recorded readings of the strain gauges for all the test specimens, $\varepsilon_{\text {smax }}$. It was noticed that none of these readings reached the yielding value that equals $2 \times 10^{-3} \mathrm{~mm} / \mathrm{mm}$. However, adding steel fiber led to a noticeable increase in the maximum recorded readings of the strain gauges. For example, $\varepsilon_{\text {smax }}$ increased by $19 \%$ when using $0.75 \%$ volumetric fibers ratio and by $45 \%$ when using $1.25 \%$ volumetric fibers ratio for series B1.

\section{Effects of Key Parameters}

\section{Effect of steel fibers volumetric ratio $\left(V_{f}\right)$}

Figure $5 \mathrm{a}$ undoubtedly shows that as fiber volumetric ratio $\left(\mathrm{V}_{f}\right)$ increased, the ultimate shear strength increased. Rate of increase in shear strength was almost constant with increasing $\mathrm{V}_{f}$ for all tested beams. Figure $5 \mathrm{~b}$ shows that as fiber volumetric ratio $\left(\mathrm{V}_{f}\right)$ increased, the ductility increased. Rate of increase in ductility was almost constant with increasing $\mathrm{V}_{f}$ for series B1, B3 and B4. Series B2 had lower rate of increase in ductility when $\mathrm{V}_{f}$ increased from $0.00 \%$ to $0.75 \%$ than when $\mathrm{V}_{f}$ increased from $0.75 \%$ to $1.25 \%$.

\section{Effect of concrete compressive strength $\left(f_{c u}\right)$}

Test results on two series; $\mathrm{B} 1$ and $\mathrm{B} 2$, were analyzed to demonstrate the effect of concrete compressive strength on SFRC wide beam behavior. Concrete compressive strength was $27 \mathrm{MPa}$ for series $\mathrm{B} 1$ and 49MPa for series B2. SFRC Beams B1-1 and B2-1 had no steel fibers, while B1-2 and B2-2 had steel fibers with volumetric ratio $0.75 \%$. B1-3 and B2-3 had steel fibers with volumetric ratio $1.25 \%$. As shown in Figure $5 \mathrm{~b}$ and Table 1, the normalized shear resistance value increased 
by $24 \%$ for specimens without steel fibers and by $13 \%$ when using $0.75 \%$ volumetric fibers ratio and by $10 \%$ when using $1.25 \%$ volumetric ratio and this enhancement in shear strength is attributed to the increase in concrete compressive strength from 27 to $49 \mathrm{MPa}$. Referring to Figure $6 \mathrm{a}$ it can be noticed that for a constant value of $(\mathrm{a} / \mathrm{d}), \rho$, and $\mathrm{V}_{f}$ the ratio "Z" was found to be higher for beams with lower grade of concrete. It can be reported that, the influence of using steel fiber on ultimate shear strength is less pronounced for high grade concrete.

On the other hand, it was observed that ductility increased in specimens with higher concrete grade because these specimens had higher ultimate load than specimens with lower concrete compressive strength. The ductility increased by $157 \%$ for specimens without steel fibers and increased by $141 \%$ and $100 \%$ for specimens with steel fibers volumetric ratios $\left(\mathrm{V}_{f}\right) 0.75 \%$ and $1.25 \%$, respectively and this enhancement in ductility is attributed to the increase in concrete compressive strength from $27 \mathrm{MPa}$ to $49 \mathrm{MPa}$ (Figure 5b). Figure $6 \mathrm{~b}$ shows that for a constant value of $(\mathrm{a} / \mathrm{d}), \rho$, and $\mathrm{V}_{f}$ the ratio between ductility for SFRC specimens and R.C. specimens was found to be higher for beams with lower grade of concrete. It can be concluded that, the influence of using steel fiber on ductility is less pronounced for high grade concrete.

\section{Effect of longitudinal reinforcement ratio $(\rho)$}

Test results on two series; $\mathrm{B} 1$ and $\mathrm{B} 3$, were analyzed to demonstrate

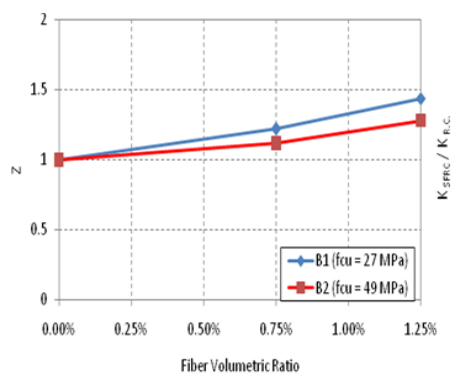

Figure 6a: Effect of concrete compressive strength on relative shear strength of $\mathrm{B} 1$ and $\mathrm{B} 2$.

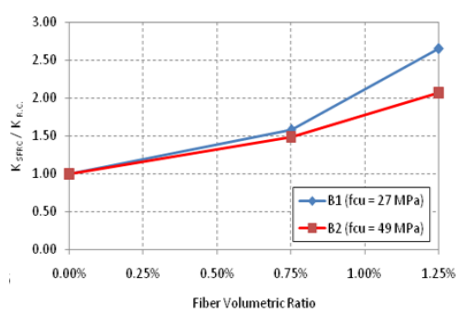

Figure 6b: Effect of concrete compressive strength on relative ductility of B1and B2.

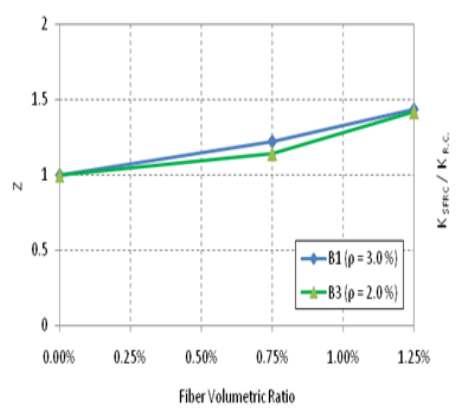

Figure 7a: Effect of longitudinal reinforcement ratio on relative shear strength of $\mathrm{B} 1$ and $\mathrm{B} 3$.

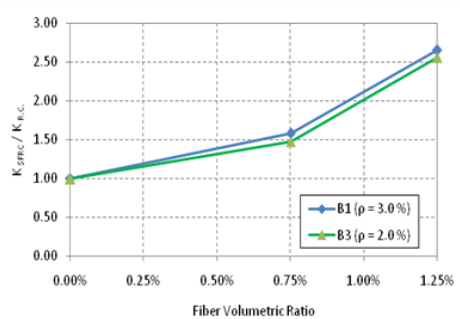

Figure 7b: Effect of longitudinal reinforcement ratio on relative ductility of B1 and B3.

the effect of longitudinal reinforcement ratio $(\rho)$ on the beam behavior. Longitudinal reinforcement ratio for series B1 was 3.0\% (6T22) and $2.0 \%$ (6T18) for series B3. Beams B1-1 and B3-1 were without steel fibers, while B1-2 and B3-2 had steel fibers with volumetric ratio $0.75 \%$. B1-3and B3-3 had steel fibers with volumetric ratio $1.25 \%$. As shown in Figure $5 \mathrm{~b}$ and Table 1, the normalized shear resistance value decreased by $22 \%$ for specimens without steel fibers and by $27 \%$ when using $0.75 \%$ volumetric fibers ratio and by $23 \%$ when using $1.25 \%$ volumetric fibers ratio as the longitudinal reinforcement ratio $(\rho)$ decreased from $3.0 \%$ to $2.0 \%$. Referring to Figure $7 \mathrm{a}$ it can be noticed that for a constant value of $(\mathrm{a} / \mathrm{d}), \mathrm{f}_{\mathrm{cu}}$, and $\mathrm{V}_{f}$ the ratio " $\mathrm{Z}$ " was found to be almost the same for series B1 and B3 which had a percentage of longitudinal reinforcement $3.0 \%$ and $2.0 \%$, respectively. It can be reported that, the influence of using steel fiber on ultimate shear strength is almost the same for different values of longitudinal reinforcement ratio $(\rho)$.

Nevertheless, the ductility increased by decreasing longitudinal reinforcement ratio $(\rho)$ from $3.0 \%$ to $2.0 \%$ as shown in Figure $5 b$ because specimens with low reinforcement ratio had more plastic deformation than other specimens. Ductility increased by $10 \%$ for specimens without steel fibers and increased by $3 \%$ and $6 \%$ for specimens with steel fibers volumetric ratios $\left(\mathrm{V}_{f}\right) 0.75 \%$ and $1.25 \%$, respectively due to the reduction in longitudinal reinforcement ratio ( $\rho$ ) from $3.0 \%$ to $2.0 \%$. Figure $7 \mathrm{~b}$ shows that for a constant value of $(\mathrm{a} / \mathrm{d}), \mathrm{f}_{\mathrm{cu}}$, and $\mathrm{V}_{\rho}$ the ratio between ductility for SFRC specimens and R.C. specimens was found to be slightly higher for beams with high longitudinal reinforcement ratio.

\section{Effect of span-to-depth ratio (a/d)}

Test results on two series; $\mathrm{B} 1$ and $\mathrm{B} 4$ were analyzed to demonstrate the effect of span-to-depth ratio on the beam behavior. Span-to-depth ratio was 1.8 for series B1 and 2.4 for series B4. As shown in Figure $5 \mathrm{~b}$ and Table 1 , the normalized shear resistance value decreased by $42 \%$ for specimens without steel fibers and by $20 \%$ when using $0.75 \%$ volumetric fibers ratio and by $22 \%$ when using $1.25 \%$ volumetric fibers ratio due to the span-to-depth ratio $(\mathrm{a} / \mathrm{d})$ increase from 1.8 to 2.4. Referring to Figure $8 \mathrm{a}$, it can be noticed that for a constant value of $\rho, f_{c u}$, and $V_{\rho}$ the ratio " $Z$ " was found to be higher for beams with high span-to-depth ratio. It may be reported that, the influence of using steel fiber on ultimate shear strength is more pronounced for flexural beams. However, the ductility increased by increasing span-to-depth ratio (a/d) from 1.8 to $2.4 \%$ as shown in Figure $5 \mathrm{~b}$. Ductility increased by $3 \%$ for specimens without steel fibers and increased by $43 \%$ and $14 \%$ for specimens with steel fibers volumetric ratios $\left(V_{f}\right) 0.75 \%$ and $1.25 \%$, respectively. Figure $8 b$ shows that for a constant value of $\rho, f_{c u}$, and $V_{\rho}$ the ratio between ductility for SFRC specimens and R.C. specimens was found to be higher for beams with high span-to-depth ratio. It may be reported that, the influence of using steel fibers on ductility is more pronounced for flexural beams. 


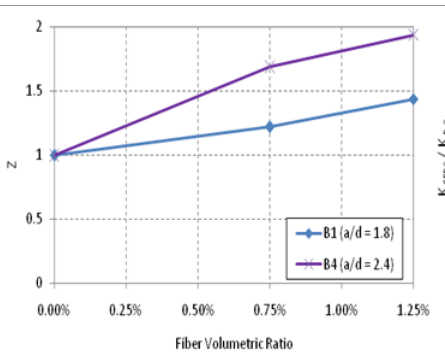

Figure 8a: Effect of span-to-depth ratio on relative shear strength of B1and B4.

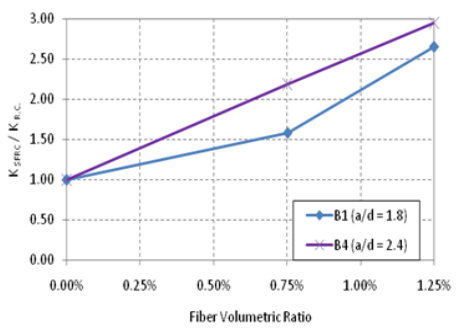

Figure 8b: Effect of span-to-depth ratio on relative ductility of B1 and B4.

\section{Analytical Predictions}

Several models have been proposed to predict shear strength of SFRC slender beams without stirrups. Some models (Type 1) consider the contribution of fiber resistance and the concrete contribution independently, in a way similar to the steel stirrups improving the shear capacity of conventional RC members, to predict the shear strength of SFRC members. Other models (Type 2) assume that the addition of steel fibers directly modifies the concrete strength in flexure, shear, and tension. Both of these models include several parameters, such as concrete compressive strength, shear span-depth ratio, percentage of longitudinal reinforcement, type of fiber, amount of fiber content, and fiber matrix bond strength. However, five different models were used to predict shear strength of the tested specimens. Most of these selected models fall under the Type 1 category.

\section{Type 2: Proposed by Sharma [11]}

Sharma proposed a simple empirical equation for predicting the shear strength of fiber-reinforced concrete beams

$$
\mathrm{v}_{\mathrm{u}}=0.67 \mathrm{f}^{\prime} \mathrm{t} /(\mathrm{a} / \mathrm{d})^{0.25}(\mathrm{MPa})
$$

Where

$(\mathrm{a} / \mathrm{b})$ shear span-depth ratio, $\mathrm{f}^{\prime} \mathrm{t}=$ split-cylinder tensile strength of concrete.

\section{Type 1: Proposed by Narayanan and Darwish [8]}

Narayanan and Darwish proposed an empirical equation for the average shear stress at shear failure

$$
\mathrm{v}_{\mathrm{u}}=\mathrm{e}\left[0.24 f_{s p f c}+80 \rho \frac{\mathrm{d}}{\mathrm{a}}\right]+\mathrm{v}_{\mathrm{b}}
$$

Where

$f_{s p f c}=$ Computed value of split-cylinder strength of fiber concrete

$$
\frac{f_{\text {cuf }}}{(20-\sqrt{F})}+0.7+1.0 \sqrt{F}(\mathrm{MPa})
$$

$F=$ fiber factor $\left(\frac{L_{f}}{D_{f}}\right) V_{f} d_{f}$;

$\rho=$ Flexural reinforcement ratio;

$\mathrm{e}=$ Arch action factor: 1.0 for $\mathrm{a} / \mathrm{d}>2.8$, and $(2.8 \mathrm{~d} / \mathrm{a})$ for $\mathrm{a} / \mathrm{d} \leq 2.8$

$f_{\text {cuf }}=$ Cube strength of fiber concrete (MPa), $L_{f}=$ fiber length

$D_{f}=$ Fiber diameter, $s s=$ volume fraction of steel fibers

$d_{f}=$ Bond factor: 0.5 for round fibers, 0.75 for crimped fibers and 1.0 for hooked $\mathrm{MPa})$.

$V_{b}=0.41 \tau F, \tau=$ average fiber matrix interfacial bond stress $(4.15$

\section{Type 1: Proposed by Ashour et al. [6]}

Ashour, Hasanain and Wafa proposed an empirical equation for the average shear stress at shear failure

$$
\mathrm{v}_{\mathrm{u}}=\left(0.7 \sqrt{f^{\prime} c}+7 \mathrm{~F}\right) \frac{\mathrm{d}}{\mathrm{a}}+17.2 \rho \frac{\mathrm{d}}{\mathrm{a}}(\mathrm{MPa})
$$

Where

$F=$ fiber factor $\left(\frac{L_{f}}{D_{f}}\right) V_{f} d_{f} ;$

$\rho=$ flexural reinforcement ratio;

$(\mathrm{a} / \mathrm{d})=$ shear span-depth ratio

$\mathrm{v}_{\mathrm{b}}=0.41 \tau F, \tau=$ average fiber matrix interfacial bond stress $(4.15 \mathrm{MPa})$

\section{Type 1: Proposed by Imam et al. [12]}

Imam and Vandewalle proposed an empirical equation for the average shear stress at shear failure

$$
\mathrm{v}_{\mathrm{u}}=0.6 \psi^{3} \sqrt{\omega}\left\{\left(f^{\prime} c\right)^{0.44}+275 \sqrt{\frac{\omega}{\left(\frac{\mathrm{a}}{\mathrm{d}}\right)^{5}}}\right\}
$$

Where

$\psi=$ size effect factor

$=\frac{1+\sqrt{\left(5.08 / \mathrm{d}_{\mathrm{a}}\right)}}{\sqrt{1+\mathrm{d} /\left(25 \mathrm{~d}_{\mathrm{a}}\right)}}$

$\mathrm{d}_{\mathrm{a}}=$ Maximum aggregate size, $\omega=$ reinforcement factor $\rho(1+4 \mathrm{~F})$;

$F=$ Fiber factor $\left(\frac{L_{f}}{D_{f}}\right) V_{f} d_{f}$;

$d_{f}=$ Bond factor: 0.5 for round fibers, 0.9 for crimped fibers and 1.0 for hooked

\section{Type 1: Proposed by Kwak et al. [1],}

They proposed an empirical equation for the average shear stress at shear failure.

$$
\mathrm{v}_{\mathrm{u}}=\left[3.7 \mathrm{e} f_{s p f c} 2 / 3\left(\rho \frac{\mathrm{d}}{\mathrm{a}}\right)^{1 / 3}+0.8 \mathrm{v}_{\mathrm{b}}\right]
$$

Where 
Citation: Morsy AM, El-Raki TM (2018) Shear Behavior of Steel Fiber Reinforced Concrete Wide Beams without Stirrups. J Civil Environ Eng 8: 292. doi: $10.4172 / 2165-784 X .1000292$

Page 8 of 9

\begin{tabular}{|c|c|c|c|c|c|c|c|c|c|c|}
\hline \multirow[b]{2}{*}{$\begin{array}{l}\frac{c}{0} \\
\frac{.}{0} \\
\frac{\Xi}{n} \\
\frac{0}{n}\end{array}$} & \multicolumn{2}{|c|}{ Sharma [11] } & \multicolumn{2}{|c|}{ Narayanan and Darwish [8] } & \multicolumn{2}{|c|}{ Ashour et al. [6] } & \multicolumn{2}{|c|}{ Imam et al. [12] } & \multicolumn{2}{|c|}{ Kwak et al. [1] } \\
\hline & $>^{\ddagger}$ & 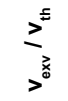 & $>^{5}$ & $\underbrace{>^{ \pm}}_{>^{\vec{x}}}$ & $>^{5}$ & $\underset{>^{\vec{x}}}{\geq^{ \pm}}$ & $>^{5}$ & $\underset{>^{\vec{x}}}{>^{ \pm}}$ & $>$ & $\underbrace{\frac{5}{5}}_{\substack{\vec{x} \\
>^{5}}}$ \\
\hline B1-1 & 2.14 & 1.34 & 2.99 & 0.95 & 2.18 & 1.31 & 3.85 & 0.74 & 3.02 & 0.95 \\
\hline B1-2 & 2.18 & 1.62 & 3.91 & 0.90 & 3.73 & 0.95 & 7.53 & 0.47 & 4.19 & 0.84 \\
\hline B1-3 & 2.17 & 1.91 & 4.40 & 0.94 & 4.74 & 0.87 & 9.70 & 0.43 & 4.69 & 0.88 \\
\hline B2-1 & 2.91 & 1.65 & 3.44 & 1.39 & 2.86 & 1.68 & 4.14 & 1.16 & 4.07 & 1.18 \\
\hline B2-2 & 2.88 & 1.86 & 4.33 & 1.24 & 4.35 & 1.23 & 7.89 & 0.68 & 5.10 & 1.05 \\
\hline B2-3 & 2.96 & 2.12 & 4.89 & 1.28 & 5.44 & 1.15 & 10.16 & 0.62 & 5.71 & 1.10 \\
\hline B3-1 & 2.22 & 1.04 & 2.33 & 0.99 & 2.17 & 1.06 & 2.95 & 0.78 & 2.76 & 0.83 \\
\hline B3-2 & 2.30 & 1.19 & 3.27 & 0.83 & 3.78 & 0.72 & 5.71 & 0.48 & 3.89 & 0.70 \\
\hline B3-3 & 2.31 & 1.48 & 3.78 & 0.91 & 4.82 & 0.71 & 7.33 & 0.47 & 4.39 & 0.78 \\
\hline B4-1 & 1.99 & 0.83 & 1.83 & 0.90 & 1.63 & 1.01 & 2.35 & 0.70 & 2.06 & 0.80 \\
\hline B4-2 & 1.99 & 1.40 & 2.66 & 1.05 & 2.77 & 1.01 & 4.31 & 0.65 & 2.99 & 0.93 \\
\hline B4-3 & 2.02 & 1.61 & 3.16 & 1.03 & 3.56 & 0.91 & 5.47 & 0.60 & 3.47 & 0.94 \\
\hline Ave. value & --- & 1.50 & --- & 1.03 & --- & 1.05 & --- & 0.65 & --- & 0.92 \\
\hline
\end{tabular}

Table 3: Shear strength prediction models for SFRC beams used in this study.

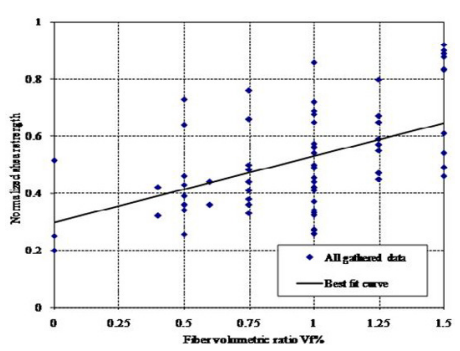

Figure 9: Relation between fiber volumetric ratio and normalized shear strength of beams.

$f_{s p f c}=$ Computed value of split-cylinder strength of fiber concrete

$F=$ Fiber factor $\left(\frac{L_{f}}{D_{f}}\right) V_{f} d_{f} ;$

$\rho=$ Flexural reinforcement ratio; $V_{b}=0.41 \tau F$

$\tau=$ Average fiber matrix interfacial bond stress (4.15 MPa).

\section{Comparison of observed values with predicted values}

Table 3 shows the values of tested shear strength, predicted shear strength and the ratio between these values. The observed values of shear strength of the SFRC specimens were in the range of $43 \%$ to $212 \%$ of the predicted values. The model proposed by Sharma [11] provided the most conservative results. Minimum safety factor was 1.19, maximum one was 2.12 and the average safety factor was 1.50 . However, the shear strength values predicted using the model proposed by Narayanan et al. [8] were much closer to the experimental values found in this study. The model proposed by Imam et al. [12] provided the most unconservative results. All specimens' safety factors were less than 1 .

\section{Proposed formula for the relationship between fiber volumetric ratio and shear strength of SFRC beams}

Regarding the large variation in equations proposed by several researchers, an effort was made in this study to establish a correlation between the fiber content and the shear strengths of the SFRC specimens using the test results as reported in the literature [1,2,5,6,8,10-16]. A total of $73 \mathrm{RC}$ and SFRC beam (including these research findings) without shear stirrups were used in this evaluation. Various properties of these beams considered are as follows: 1$)$ shear span depth ratio (a/d) $\geq 1.8$; 2) longitudinal tension reinforcement ratio $\rho$ ranging between $1.2 \%$ and $4.5 \%$; 3 ) concrete compressive strength $\mathrm{f}_{\mathrm{cu}}$ varied from 25.0 to $60.0 \mathrm{MPa}$; 4) hooked steel fibers in volume fractions $\mathrm{V}_{f}$ varied from 0 to $1.5 \%$; and 5) fiber length-diameter ratio $\left(\mathrm{L}_{f} / \mathrm{D}_{f}\right)$ varied from 55 to 100. The measured shear strengths $V_{u}$ of test beams were normalized with respect to their corresponding ( $b \mathrm{f}_{\mathrm{cu}}{ }^{0.5}$ ) values. Figure 9 shows the relation between normalized shear stress $\left(\mathrm{V}_{\mathrm{u}} / \mathrm{bd} \mathrm{f}_{\mathrm{cu}}^{0.5}\right)$ and the fiber content. Using a curve-fitting procedure, a best-fit line was drawn and the relationship between the average shear strength and the fiber content of SFRC beams can be expressed as follows:

$$
\mathrm{V}_{\mathrm{u}} / \mathrm{bd} \mathrm{f}_{c u}{ }^{0.5}=0.27+0.2 \mathrm{~V}_{f} \mathrm{MPa}
$$

Due to the limited test data available for the SFRC beams with $2 \%$ fiber content, the correlation is established only up to a fiber content of $1.5 \%$, a value regarded as the upper limit in the practice. This proposed equation is valid for the beams with the normal-strength concrete. It should be noted that the proposed equation uses only a single variable which is fiber volume ratio $V_{f}$ to compute the shear strengths of SFRC beams so it may provide an approximate estimate of the average value of shear strength of SFRC beams to be used in the design process.

\section{Conclusions}

Based on the study presented herein, the following conclusions have been drawn:

1. The addition of $0.75 \%$ steel fiber content in the SFRC beams without shear stirrups is sufficient to achieve the ultimate shear resistance that is the same as the conventional RC member with steel stirrups.

2. In order to achieve a reasonable level of ductility before shear failure of the SFRC member without stirrups, a fiber dose equal to or more than $1.25 \%$ is required. However, higher doses of fiber content significantly decrease the workability of concrete mixture which represents a drawback for using steel fibers.

3. Increasing concrete compressive strength of SFRC wide beams increases the shear strength and increases its ductility. Nevertheless, the increase in shear strength due to fiber content is less pronounced for high grade concrete.

4. Increasing longitudinal reinforcement ratio $(\rho)$ in SFRC wide beams increases the shear strength and decreases the ductility. It was noticed that the relative increase in shear strength due to fiber content was almost the same for different values of $(\rho)$. 
Citation: Morsy AM, El-Raki TM (2018) Shear Behavior of Steel Fiber Reinforced Concrete Wide Beams without Stirrups. J Civil Environ Eng 8: 292. doi: $10.4172 / 2165-784 X .1000292$

5. Increasing shear span-to-depth ratio $(\mathrm{a} / \mathrm{d})$ of SFRC wide beams decreases the shear strength and increases its ductility. Test results showed that the relative increase in shear strength due to fiber content was more efficient for higher value of $(\mathrm{a} / \mathrm{d})$.

6. The existing models available in the literature to predict the shear strengths of SFRC members without shear stirrups were adopted for slender beams. However, most of these models give a reasonable estimate of the shear strengths for SFRC wide beams.

7. Of the existing models for predicting the ultimate shear strength, the model proposed by Sharma was the most conservative one, while the model proposed by Narayanan et al. was much closer to the experimental values found in this study.

8. A new simple expression relating the fiber volumetric ratio to the shear strengths of SFRC beams was proposed using a large set of test results.

\section{References}

1. Kwak YK, Eberhard MO, Kim WS, Kim J (2002) Shear strength of steel fiberreinforced concrete beams without stirrups. ACI Struct J 99: 530-538.

2. Dinh HH, Parra-Montesinos GJ, Wight JK (2010) Shear behavior of steel fiber reinforced concrete beams without stirrup reinforcement. ACI Struct J 107:597-606.

3. Batson G, Jenkins E, Spatney R (1972) Steel fibers as shear reinforcement in beams. ACI Journal Proceedings 69: 640-644.

4. Li VC, Ward R, Hamza AM (1992) Steel and synthetic fibers as shear reinforcement. ACl Mater J 89: 499-508.

5. Mansur MA, Ong KCG, Paramasivam P (1986) Shear strength of fibrous concrete beams without stirrups. J Struct Eng, ASCE 112: 2066-2079.

6. Ashour SA, Hasanain GS, Wafa FF (1992) Shear behavior of high-strength fiber reinforced concrete beams. ACI Struct J 89:176-184.

7. Madhusudan K, Stojadinovic B, Goel SC (1999) Shear strength of normal and high-strength fiber reinforced concrete beams without stirrups. ACI Struct J 96 : 282-289.

8. Narayanan R, Darwish IYS (1987) Use of steel fibers as shear reinforcement ACl Struct J 84: 216-227.

9. $\mathrm{ACl}$ (2010) Building code requirements for structural concrete (ACl 318-08) and Commentary (318R-05), American Concrete Institute, Farmington Hills, Michigan, USA.

10. Mansur MA, Ong KCG (1991) Behavior of reinforced fiber concrete deep beams in shear. ACI Struct J 88: 98-105.

11. Sharma AK (1986) Shear strength of steel fiber reinforced concrete beams. ACl Journal Proceedings 83: 624-628.

12. Vandewalle MI, Mortelmans F (1994) Shear capacity of steel fiber high-strength concrete beams, high-performance concrete, American Concrete Institute, Special Publication 149: 227-241.

13. Said M, El-Rakib TM (2013) Enhancement of shear strength and ductility for reinforced concrete wide beams due to web reinforcement. HBRC Journal 9: 235-242.

14. Ghada D (2009) Shear behavior of slurry infiltrated fiber reinforced concrete beams. Doctor of Philosophy, Structural Department, faculty of Engineering, Cairo University, 2009.

15. Adebar P, Mindess S, St. Pierre D, Olund B (1997) Shear tests of fiber concrete beams without stirrups. ACI Struct J 94: 68-76.

16. Aoude H, Belghiti M, Cook WD, Mitchell D (2012) Response of steel fiberreinforced concrete beams with and without stirrups. ACI Struct J 109: 359-367. 